This item was submitted to Loughborough's Research Repository by the author.

Items in Figshare are protected by copyright, with all rights reserved, unless otherwise indicated.

\title{
Paying for water services: effects of household characteristics
}

PLEASE CITE THE PUBLISHED VERSION

http://dx.doi.org/10.1016/S0957-1787(03)00034-1

PUBLISHER

(c) Elsevier

VERSION

AM (Accepted Manuscript)

LICENCE

CC BY-NC-ND 4.0

REPOSITORY RECORD

Kayaga, Sam, John Calvert, and Kevin Sansom. 2019. "Paying for Water Services: Effects of Household Characteristics". figshare. https://hdl.handle.net/2134/9707. 
This item was submitted to Loughborough's Institutional Repository (https://dspace.lboro.ac.uk/) by the author and is made available under the following Creative Commons Licence conditions.

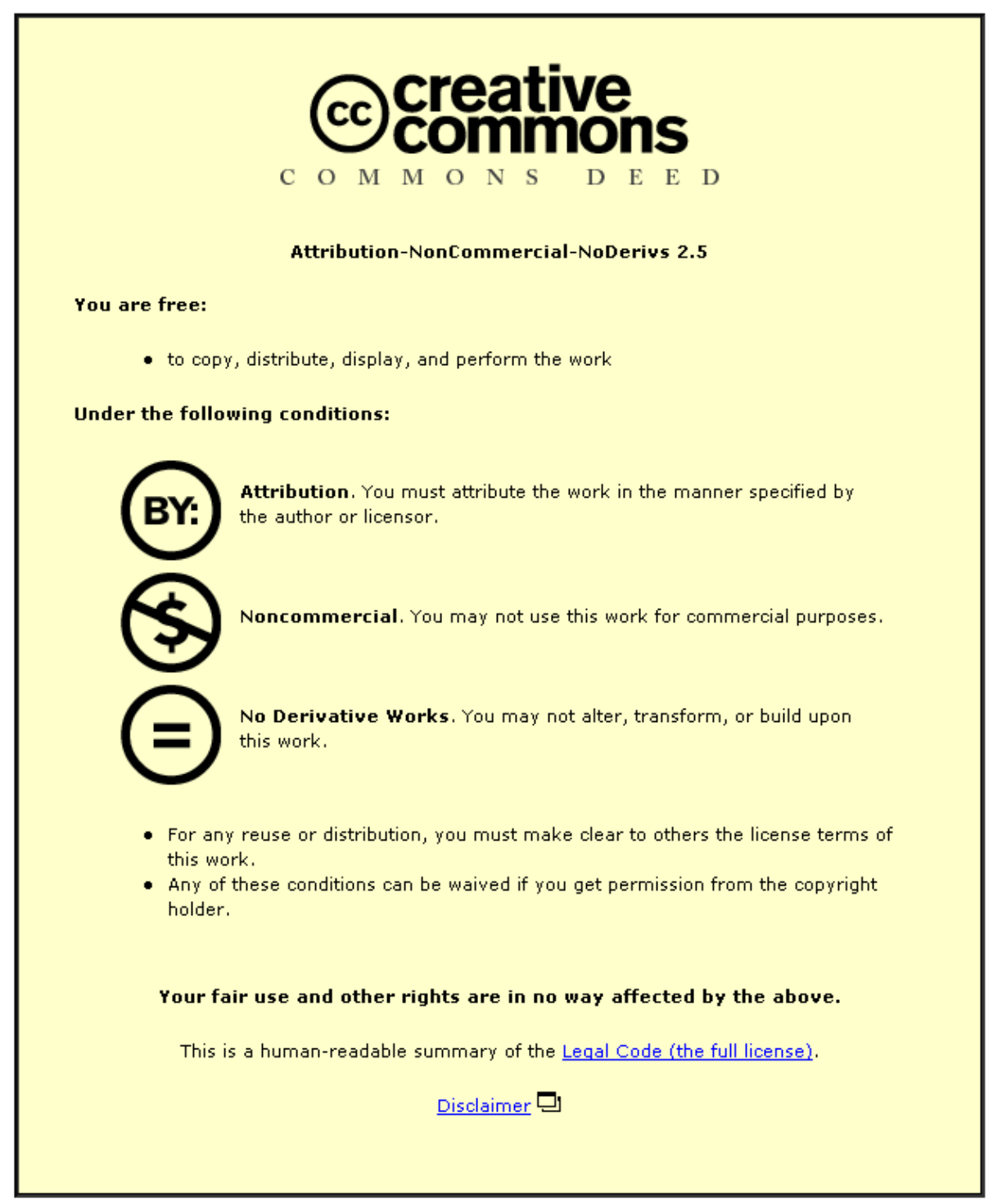

For the full text of this licence, please go to: http://creativecommons.org/licenses/by-nc-nd/2.5/ 


\section{Paying for Water Services:}

\section{Effects of Household Characteristics}

by

"Dr. Sam Kayaga, Water Engineering and Development Centre, Loughborough University, Leicestershire, LE11 3TU, The United Kingdom; Telephone +44-1509-228743; Fax +44-1509-211079; Email s.m.kayaga@lboro.ac.uk

and

Dr. John Calvert, Business School, Loughborough University, Leicestershire, LE11 3TU, The United Kingdom;

and

Mr. Kevin Sansom Water Engineering and Development Centre, Loughborough University, Leicestershire, LE11 3TU, The United Kingdom.

\footnotetext{
\# All correspondences concerning the manuscript should be addressed to the principal author
} 


\section{Abstract}

Keywords: $\quad$ urban water services, cost recovery, household characteristics

Maximising cost recovery is currently a top priority for managers of urban water utilities in low-income countries. This research was carried out in 11 major towns of Uganda to establish which household characteristics influence payment for water services. A questionnaire was used to collect data on Customer Satisfaction, Customer Loyalty and several socio-economic variables. Using regression techniques, it was established that the following attributes of the household head moderated the satisfaction/loyalty relationship: gender, occupation and level of education. Other significant factors were household income, and property tenure status. These results could be used to make water utilities customer-focused. 


\section{Introduction}

Access to improved service levels of sanitation and water supply is not only vital for human health but is also necessary for the people's convenience and dignity. Various research findings point to substantial health and economic benefits for households and individuals as a result of improved water supply and sanitation. Yet data compiled by the Water Supply and Sanitation Collaborative Council at the end of the last millennium revealed a large service gap in low-income countries. In Africa, for example, a continent with an estimated population of 784 million people in the year 2002, only $62 \%$ had access to 'improved' water supply, while $60 \%$ were served by 'improved' sanitation (WHO/UNICEF, 2000). 'Improved' water supply was described as one of the following service options: household connections, public standpipes, boreholes, protected dug wells, protected springs, or rainwater collection. 'Improved' sanitation included public sewer connections, septic tank connections, pour-flush latrines, simple pit latrines, and ventilated improved latrines.

National governments, and water sector professionals in low-income countries, together with their development partners, are thus faced with a daunting task to improve the management of water resources and accelerate water supply and sanitation coverage to all the people. The task of ensuring service delivery is greater in urban areas of lowincome countries, where, it is projected that $88 \%$ of all the increase in 
global population will live by 2015 (WHO/UNICEF, 2000). In order to meet these challenges, there is need to recover costs of services delivered. Although most consumers have low levels of income, research carried out in low-income countries has shown that cost recovery leads to more efficiency, higher effectiveness and greater sustainability (Evans, 1992; Katko, 1991).

In order to increase levels of cost recovery, utility managers in lowincome countries need to gain a deeper understanding of what factors influence customers' willingness to pay for water services. Since the beginning of the International Water and Sanitation Decade (19801990), a few studies have been conducted in various low-income countries to establish factors that influence Willingness-To-Pay (WTP) for water services. In the research reports reviewed, most WTP studies have been carried prior to or at the commencement of a water project. Most of these studies have utilised a contingent valuation method (CVM), whereby a hypothetical market is specified for a non-market commodity, and individual households are asked, through various methods, about the value placed on the commodity (Bohm, Essenburg and Fox, 1993).

This research builds on earlier work carried out on WTP for water services in low- and middle-income countries. The purpose of this research was to establish the influence of household characteristics on the willingness of existing customers to sustain cost recovery for urban 
water services. As a departure from previous research practice, however, this study did not use contingent valuation surveys, a methodology grounded in econometric models, which is often applied for willingness-to-pay studies in the water and sanitation industry. This research utilised the behavioural sciences models that are predominantly utilised in most services management and marketing research.

\section{Factors Affecting WTP for Water Services}

A few case studies have been carried out on factors affecting WTP for water services. A study conducted in Lugazi, a 20,000-resident town in Uganda, in 1994 on WTP for improved water services revealed that most households were willing to pay more for private connections than for accessibility to a public tap (Whittington, Davis and McClelland, 1996). Given depressed income levels of residents, the same study recommended spreading of capital costs for new household connection over a reasonable period of time. Similar results were obtained in studies carried out in the province of Punjab of Pakistan (Altaf, Whittington, Jamal and Kerry, 1993), Anambra State of Nigeria (Whittington, Okarafor, Okore and McPhail, 1990), cities of Ahmedabad and Bangalore of India (Mani, Onishi and Kidokoro, 1997), rural villages of Phillipines (Bohm, Essenburg \& Fox, 1993), 
and the city of Delhi in India (Zerah, 1997). Indeed, the results of a study carried out in Punjab, Pakistan showed that households were prepared to pay substantial amounts of money for private house connections, only if the service was reliable (Altaf et al., 1993).

Other research findings have highlighted the importance of water quality in determination of effective demand for water services. In research carried out in the Asian continent, Asian Development Bank (1999) found that an individual is prepared to pay a relatively higher price for a product perceived to have a higher water quality. Water quality was defined in terms of chemical and biological composition, taste and smell, water pressure, reliability of supply, accessibility and convenience. Similarly, the results of a study conducted in Punjab, Pakistan (Altaf et al., 1993) showed that service characteristics of most concern to households are reliability and water quality. Another study carried out in rural parts of Philippines showed that households value in-house piped water supply highly relative to other characteristics of their homes (North and Griffin, 1993).

Reasons for lower WTP for public utility services in Anambra State of Nigeria (Whittington, Okorafor, Okore and McPhail, 1990) were: (i) depressed affordability and non-flexibility of monthly payments; (ii) ignorance of the magnitude of current expenditure on vended water; and (iii) respondents' expectation of free or subsided services from the government. Similar results were obtained in a study carried out in 
Kerala, a coastal state in India (Jacob, 1992), where consumers considered drinking water supply as part of welfare programmes of the government. Similarly, Altaf et al. (1993) found that tariffs and connection fees were significantly negatively affecting the likelihood of households in Punjab, Pakistan to connect to public water systems. Indeed, a WTP study conducted in Kerala (India) showed if the monthly tariff was kept constant, and the connection cost reduced seven times, net revenue for the water utility would go up four times (Singh, Ramasubban, Bhatia, Briscoe, Griffin and Kim, 1993).

In the early 1990s, The World Bank Water Demand Research Team (World Bank, 1993) carried out case studies on demand for improved water services in selected regions of Latin America, Africa, and South Asia on demand for water. The general findings in respect of factors affecting WTP may be summarised as follows:

○ Better-educated household members were willing to pay more for improved water supplies than the lowly educated consumers.

○ Women were willing to pay more for better water services than male respondents.

○ Respondents employed in the formal sector generally displayed better WTP for improved services than those employed in informal sector. 
- There was no significant effect of family size and composition on WTP for improved services.

- The more an improved water source costed in terms of capital, recurrent monetary costs, and time, the less likely a household chose it.

- A household was more willing to pay for an improved source when the perceived water quality of the alternative sources was poorer.

o Households were willing to pay much more if the water from an improved source was reliable.

○ Most households were willing to pay more for private connections than for access to a public tap.

○ Respondents' sense of entitlement and equity through government services was found to be an obstacle to paying realistic prices for water services.

As pointed out earlier, most of the research enumerated above was carried out prior to, or at the implementation of water supply improvement projects. Furthermore, most of previous research has been conducted in rural areas, rural growth centres and small towns, This research was, however, conducted among existing customers of an urban water utility. The next section describes the conceptual framework used in the research. 


\section{Conceptual Framework}

This study was part of a wider research undertaken for a university academic qualification (Kayaga, 2002). The hypothesis addressed by this article is:

The following household characteristics will have significant moderator effects on the relationship between Customer Satisfaction and Customer Loyalty towards the urban water utility:

a. Gender of head of household

b. Number of years spent in formal education by head of household

c. Type of occupation of head of household

d. Number of people in household

e. Ownership status of the residence occupied by household

f. Type of premises occupied by household

g. Household income

h. Use of alternative water supply by household

The conceptual model for this research is shown in Figure I. In a similar way to other services management research, this study has adopted the approach predominantly applied by social psychologists in the conceptualisation of moderating variables. A moderating variable 
affects the degree or form of the relationship between a criterion variable and a predictor variable in one or more of the following ways: (i) whether the relationship will exist or not; (iii) the strength of the relationship; and/or (iii) the direction of the relationship (Baron and Kenny, 1986; Kervin, 1992; Sekaran, 1992). In this research, the criterion variable is Customer Loyalty, and the predictor variable is Customer Satisfaction. The proceeding sections provide brief definitions of the research variables.

Insert Figure I

Customer Loyalty

There are various definitions of Customer Loyalty in services management literature. For the purpose of this research, Customer Loyalty is defined as the positively biased behavioural response towards the service organisation, expressed by a customer over time, which response is a function of decision-making and evaluative processes, resulting into commitment (Bloemer, de Ruyter and Peeters, 1998). In this research, Customer Loyalty has been conceptualised as the customer's expressions of affection and anticipated commitment to biased behavioural response in favour of the water utility. 
Ensuring loyalty for urban water utilities in low-income countries is necessary for enhancing willingness to sustain payment for delivered services, leading to a lower unaccounted-for-water and a high bill collection efficiency. Customer Loyalty is more important for utilities where a big fraction of non-revenue water is as a result of administrative losses, due to consumers' practices that are characteristic of low willingness-to-pay for services, such as illegal connections/reconnections, meter defilement, and under-billing through collusion with utility staff. Many urban water utilities in Africa have non-revenue water higher than 50\% (WUP, 2000), as there are alternative sources of water supply; and/or organisational systems are too weak to contain the administrative losses.

In order to break from a cycle of poor corporate performance that is common in the public sector of many low-income countries, utility managers need to adapt business principles used by private services managers, such as creation of customer loyalty. It is tempting for organisations to be preoccupied with winning new customers at the expense of existing ones. However, in a service environment where there are alternative sources of water supply, albeit with inferior quality, customers who are loyal to the water utility could create a ripple effect in the organisational performance. In the first instance, the loyal customers will pay their bills promptly, which will lead to higher utility revenues. Furthermore, the loyal customers may increase their business dealings with the utility, by signing up for other utility 
products, such as sewerage connections. Loyal customers may also boost business performance of utilities by attracting new customers through positive word of mouth.

\section{Customer Satisfaction}

The definition of Customer Satisfaction commonly used in services management literature is based on the comparison standards model, which posits that customers hold pre-consumption product/service standards, observe product/service performance, compare performance with their standards, and form confirmation or disconfirmation perceptions. They combine these perceptions with standard levels to form summary satisfaction judgements (Oliver, 1980; Walker, 1995). The comparison standards model holds that Customer Satisfaction is related to both the direction and the size of the disconfirmation, with three possible outcomes. Confirmation will lead to moderate satisfaction, positive disconfirmation will lead to high satisfaction, and negative disconfirmation will lead to dissatisfaction (Churchill and Surprenant, 1982; Iacobucci, Ostam, Braig, and Bezjian-Avery, 1996; Oliver, 1980; Walker, 1995). Previous research carried out in various service settings has shown that Customer Satisfaction is a strong predictor of Service Loyalty. 


\section{Moderating Variables}

The moderating variables were selected basing on two criteria:

1. Household variables that have been investigated and reported in the literature to have influence on Willingness-To-Pay for water services. The findings have been briefly highlighted in Section Two.

2. Household variables that could easily be measured within the scope of the research.

A brief description of each variable follows.

\section{Gender of Head of Household}

Gender of head of household is expected to have moderating effects on the satisfaction-loyalty relationship. Traditionally, women in lowincome countries, with the help of their children, are usually the primary collectors, users and managers of water in the household (Halvorson, Aziz and Alibhoy, 1998; Jamal, 1998). If, for any reason or another, water services to the household are interrupted, women will be most affected in the home, in terms of extra energy and opportunity cost of providing water from alternative sources . It is therefore proposed that compared to a male, a female who is in charge of 
making decisions about payment for water services in a household, will have a more favourable attitude towards the utility, to ensure service continuity.

\section{Level of Education of Head of Household}

More educated heads of households are expected to have a higher appreciation of the importance of cost recovery for sustainability of service delivery. This is probably because they have a higher opportunity cost for time spent collecting water from off-plot alternative sources, and prefer engaging in other more productive tasks. The level of education will be measured by number of years spent on formal education.

\section{Type of Occupation of Household Head}

Many household heads in urban areas of low-income countries are engaged in informal employment, where they receive wages irregularly. In fact, most of such workers receive their wages on a daily basis, with no job security for the rest of the month. For such people, it would be difficult to cope with utility bills delivered on a monthly basis. It is therefore expected that household heads who are in formal employment would display higher action loyalty, than their counterparts who are in informal employment. 


\section{$\underline{\text { Size of Household }}$}

It is predicted that the larger the size of the household, the more favourable a household will be towards payment of water bills, as absence of water in a home would cause more inconvenience for a larger household. Besides, it would be easier for a smaller household to receive water from a neighbour at a smaller or zero cost than for a larger household.

\section{$\underline{\text { Tenure Status }}$}

Ownership status of the residential house, and family occupancy density are also predicted to moderate the satisfaction-loyalty relationship, in view of the policy of the water utility in Uganda to deliver bills to the landlords. Nearly $55 \%$ of people living in urban centres of Uganda live in rented premises, some of which are shared by different families (Uganda Statistics Department, 1994). It is anticipated that customers who live in owner-occupied premises will display better willingness to pay for services, than those living in rented properties. The willingness-to-pay is expected to be even lower if several families share one property, because of low agreement on shared bills. 


\section{Estimated Household Income}

Given the same level of satisfaction, households with a higher disposable income are more likely to respond faster to water bills than households with lower income levels. This is because households in the former category have a higher ability to pay for utility services, than those in the latter category.

\section{Use of Alternative Sources of Water Supply}

It is also predicated in the research framework that a household with an alternative source of water will have a lower willingness-to-pay for services regardless of the level of customer satisfaction. Households use alternative sources of water supply for various reasons. It could be because of low affordability. On the other hand, households could actually have the capacity to pay for the services, but they might perceive utility water to be expensive. Another reason could be that households consider alternative water supply easier and more convenient to access. 


\section{Methodology}

Household data were collected through a cross-sectional survey, conducted in 11 major towns of Uganda, where a government-owned corporation, the National Water and Sewerage Corporation (NWSC), provides urban water services. All the towns included in the study had populations of at least 50,000 people, and their billing systems were computerised. The total number of households in the sampling frame was 32,114. Using Statistical Package for the Social Sciences (SPSS) computer program, a three percent random sample was drawn, giving a theoretical sample size of 1051 . This sample size was refined to exclude households with practical barriers, making an effective sample size of 846 .

As there was no readily available research instrument that could be adopted or adapted to conform to the research model, a new measurement instrument was developed. A literature review was conducted to enable development of operational definitions of the constructs, design the scale format, and generate questionnaire items. Following suggestions made during a focus group discussion by water utility managers from NWSC, a first draft of the questionnaire was produced, which was pretested with 30 postgraduate students of Uganda Management Institute. The comments made by the management students enabled refinement of the questionnaire, which was sent out for a pilot study with 106 customers of NWSC in 
Kampala. The results of the pilot study were analysed in terms of reliability and factor analyses, on the basis of which the questionnaire was refined further, and thereafter sent out for the main study.

The questionnaire had a total of 28 items, divided into the following sections: customer satisfaction (11 items), customer loyalty (8 items), and demographic/socio-economic data (9 items). The questionnaires were sent out at the end of 1999, using two modes of questionnaire administration. Respondents who claimed to be literate were asked to fill in the questionnaires themselves. On the other hand, enumerators read out and explained the questionnaire to respondents who claimed to be illiterate and/or unable to understand some/all of the contents of the questionnaire. Use of two methods of questionnaire administration raised the response rate considerably. Out of a net sample size of 690 questionnaires that were actually delivered to potential respondents, 537 useable responses were returned, giving an effective response rate of $78 \%$.

\section{Empirical Results}

Socio-economic Data

Table I shows household characteristics as reported by the respondents. 
Insert Table I

Of the 523 family heads who answered the questionnaire, $39 \%$ were women. Most of the respondents (91\%) reported to have had a formal education level of at least seven years, which differs from the 1991 national census results that put the percentage of the same category at 58\% (Uganda Statistics Department, 1994). Respondents could have exaggerated their educational status. Despite the reportedly high education standards, only $43 \%$ of the respondents claimed to be in formal employment. About $60 \%$ of the respondents reported that their household size was above five people, while 37\% reported a household size of 3-5 people. While $55 \%$ of the respondents lived in detached houses, the rest lived either in semi-detached houses (31\%), or flats (14\%). About half of the respondents received their water services through house connections, $40 \%$ of which had a yard tap as well. However, 225 respondents (43\%) only received water services through the basic yard tap service level. Forty-four respondents (8\%) received water through public standpipes or kiosks.

In order to estimate household income levels shown in Table I, household expenditures as reported by respondents were used as proxy indicators. The household expenditure levels were elicited through several questions that provided a framework for working out monthly and seasonal household expenditures. The items that formed a basis on which the household expenditure was estimated were (i) utility 
services such as water/sanitation, electricity, telephone; (ii) transport requirements; (iii) entertainment; (iv) newspapers; (v) rent or equivalent; (vi) tuition fees for family members; (vii) weekly expenditure on food items and other household requirements; and (viii) household savings, if any.

Tests for Reliability and Validity

As presented in the section on methodology, data were collected using a questionnaire that was designed by the author. Therefore, there was a need to perform psychometric analysis, in order to assess the reliability and validity of the measurement instrument. Details of the psychometric analysis are provided in Appendix 1. The statistical tests confirmed that the scales used to measure Customer Satisfaction and Customer Loyalty are reliable. Additionally, the results of factor analysis presented in Appendix 1 provide evidence of construct validity of the research instrument.

Tests for Moderator Effects

Statistical analysis was used to verify whether individual household characteristics have significant moderator effects on the relationship between Customer Satisfaction and Customer Loyalty. Detailed 
analysis is presented in Appendix 2. The results showed that the following household characteristics had significant moderator effects, in descending order of magnitude:

1. Gender of the head of household

2. Number of years spent by household head on formal education

3. Type of occupation of head of household (whether formal or informal)

4. Estimated household income

5. Whether house occupied by household is family-owned or not

Three of the hypothesized household characteristics did not have significant moderator effects at $\alpha=0.05$. These are (i) use of alternative water sources; (ii) household size; and (iii) whether the premise is shared or not.

\section{Discussion}

As indicated in the previous section, five of the eight test variables had significant moderator effects on the relationship between Customer 
Satisfaction and Customer Loyalty. The findings show that for a given level of satisfaction, female heads of households are more likely to pay for their water bills, than men. As already stated in the section on conceptual framework, in most households in Uganda, women have the responsibility for provision of basic necessities that require water, such as preparation of food and general hygiene in the home. It is not surprising, therefore, that women are keener on payment of water bills, so that provision of water services is not interrupted.

The role of level of education of the head of the household on the satisfaction/loyalty relationship was confirmed, as hypothesized in the conceptual framework. It appears that education improves the awareness of decision-makers in the home, such that they attach more value to a better quality water source. This is probably because more educated respondents attach a higher opportunity cost for time spent collecting water from other sources, hence freeing more time to engage in more valuable tasks. Furthermore, compared to the poorly educated people, those with higher education are more likely to appreciate the unique nature of potable water in terms of economic, social and environmental externalities.

The results of this study also show that heads of households who are engaged in formal employment, have a higher willingness to pay for water bills, than heads of households engaged in informal employment. These moderator effects may partly be explained by the fact that 
people employed in formal employment get monthly wages/salaries at the end of the month, which period coincides with the billing cycle of the water utility. On the other hand, people engaged in informal employment get their wages in discrete portions almost on a daily basis. When the water bills are delivered at the end of the month, these households are most likely to have spent all the money on other necessities of life, and may not pay the bills in time. Perhaps utilities could learn a lesson from this finding, and tailor the bill payment methods to the needs and means of the heterogeneous clientele.

Consistent with the discussion on the conceptual framework, ownership status of the house being occupied has significant moderator effects on the satisfaction/loyalty relationship. Since water service connections in Uganda are registered in the name of the landlords, the water bills are also dispatched in the names of landlords. Change of occupancy is a common occurrence for tenants in urban areas of Uganda. The results of this study show that for a given satisfaction level, families staying in houses owned by the household have a higher willingness to pay for water bills, than those staying in rented premises. Since households that stay in rented premises do not enter into legal contracts with the water utility, they have a lower willingness to pay for water bills, as they feel no legal obligation to the water utility. 
The findings of this study show that estimated income levels moderate the satisfaction/loyalty relationship. As hypothesized in the conceptual framework, households with a higher estimated income have a higher willingness to pay than those households with a lower estimated income. Not only do families with a higher income have a higher affordability to pay, but are also those households most likely live in family-owned premises, as well as to have heads of families who are highly educated. Correlation analysis of obtained data support the relationship of household income with the level of education of the head of household $(\rho=0.24, p<0.01)$; and with ownership status of the premises $(\rho=0.20, p<0.01)$.

The results of this research shows that 'household size', 'type of premises (whether shared or not)', and 'use of alternative sources of water' did not have statistically significant moderator effects. These results may have been affected by biases in data collection. For the household size, a number of African cultures consider it to be taboo to 'count' the number of children in a home. Consequently, some respondents may have falsified the household size intentionally. Another cause of inaccuracies in the size of household could be underdeclaration of the numbers, just in case the water utility needs to use a flat tariff rate based on household size, as in the case of a meter failure. For the type of premises, respondents may not want to tell the truth if families are sharing the same building, as it is considered socially demeaning. 
In the case of alternative water sources, inaccuracies may have been introduced by the confusion about the conceptual definition of 'alternative water sources'. According to the results, 253 respondents (48\%) reportedly use alternative sources. However, of that number, 168 respondents use either "a utility tap elsewhere", "water vendors", and/or "tanker water", sources which are, to a great extent, mere service options of the utility water supply. It would seem that most consumers use alternative service options as a coping strategy in the event of non-availability of piped water in the home, for one reason or another. The reasons for non-availability of tap water in the home could be either disconnection due to non-payment, or water supply shortage. Other economic reasons, which are particularly applicable to households using off-plot utility water taps, could be either (i) owners of private connections opting for cheaper water services at public taps in certain circumstances; or (ii) customers who opt for services which are perceived as 'free', such as illegal connections, or connections paid for by government institutions, which have limited accountability.

\section{Implications for Water Utility Managers}

These research findings have several implications for improving cost recovery in urban water utilities in low-income countries. Water utility managers should take advantage of the higher loyalty exhibited by 
women to improve cost recovery. With the gender mainstreaming movement sweeping many low-income countries, women are increasingly becoming major or equal partners on household budgetary issues. It is anticipated that media messages and other types of information targeted at the women in the households will yield more positive payment behaviour for water bills.

Water utility managers could also take advantage of the bettereducated clientele to act as utility promotion agents, assuming that the better educated have sizeable influence in their areas of residence. Furthermore, water utility managers could sponsor school programmes aimed at educating the young generation on the basic principles of the need for cost recovery for water services. The pupils and students would, in addition to gaining knowledge for their benefit, also work as change agents with the older members of the households.

Well-educated customers demonstrate good payment behaviour, probably because they are better informed about the commercial realities of running a water utility. There is therefore merit for utilities in developing countries to devote more resources to promotional campaigns informing all customers about the services being provided and the financial obligations of sustaining reliable services. This has been a common strategy used by international operators for some time. 
The findings also highlight the consequences of lack of contractual responsibilities for the tenants, as regards water services. Water utility managers should devise means of creating legal contracts (or service agreements) directly with the consumers, so they are liable for bills sent on account of water services supplied to them, other than creating contracts with only the landlords.

This research has shown that the geo-demographic characteristics of 'type of house occupied', 'employment type for household head' and 'estimated income levels' are important factors of WTP for services. These characteristics may be used to draw market segments of a water service area. The water utility managers could refine these market segments and use them to deliver differentiated service levels, at different prices, for the benefit of all consumers and the utility (Sansom, Coates, Njiru and Franceys, 2000). Carefully selected market segments or consumer groups could also be used to develop welltargeted utility promotion strategies that address the preferences and needs of people within each of those market segments. In this way, the water utilities will become customer-focused, a business philosophy that has been proven to enhance corporate success for service organisations (Slater and Narver, 1994). 


\section{References}

Altaf, M A., Whittington, D, Jamal, H and Kerry, V K (1993)

'Rethinking Rural Water Supply Policy in Punjab, Pakistan' Water

Resources Research 29 (7) 1943-1954

Asian Development Bank (1999) Handbook for the Economic Analysis of Water Supply Projects, Author

Baron R M, and Kenny, D A (1986) 'The Moderator-Mediator

Variable Distinction in Social Psychological Research: Conceptual, Strategic, and Statistical Considerations' Journal of Personality and Social Psychology 51 (6) 1173-1182

Bloemer, J, de Ruyter, K, and Peeters, P (1998) 'Investigating Drivers of Bank Loyalty: The Complex Relationship Between Image, Service Quality and Satisfaction' International Journal of Bank Marketing 16 (7) $276-286$ 
Bohm, R A, Essenburg, T J, and Fox, W F, (1993) 'Sustainability of Potable Water Services in the Philippines' Water Resources Research 29 (7) $1955-1963$

Bohrnstedt, G W, and Knoke, D, (1982) Statistics for Social Data Analysis Illinois, F E Peacock Publishers Inc

Caruana, A, Money, A H, and Berthon, P R (2000) 'Service Quality and Satisfaction - The Moderating Role of Value' European Journal of Marketing 34 (11/12) 1338-1352

Churchill, G A, Jr, and Surprenant, C (1982) 'An Investigation into Determinants of Customer Satisfaction' Journal of Marketing Research $19491-504$

Coolican, H (1994) Research Methods and Statistics in Psychology $2^{\text {nd }}$ edition London, Hodder and Stoughton 
Dielman, T E (1991) Applied Regression Analysis for Business and Economics Boston, PWS-KENT Publishing Company

Evans, P (1992) Paying the Piper: An Overview of Community Financing of Water and Sanitation, Occasional Paper 18 The Hague, IRC International Water and Sanitation Centre

Halvorson, S J, Aziz, N, and Alibhoy, K (1998) 'Strategies to Involve Women in Water Supply and Sanitation' in Pickford, J (ed) 24th WEDC Conference Proceedings on Sanitation and Water for All Loughborough, WEDC, Loughborough University

Hardy, M A (1993) 'Regression with Dummy Variables' in LewisBeck, M. S, (ed) Regression Analysis: International Handbooks of Quantitative Applications in the Social Sciences Vol. 2 London, Sage Publications Inc 
Iacobucci, D, Ostram, A M, Braig, B M , and Bezjian-Avery, A. (1996) 'A Canonical Model of Consumer Evaluations and Theoretical Bases of Expectations' in Swartz, T A, Bowen, D E, and Brown, S W (eds) Advances in Services Marketing and Management Volume 5 London, JAI Press Inc

Jacob, T V, (1992) 'Sustainability of Drinking Water Supply Schemes' in Pickford, J (ed) 18th WEDC Conference Proceedings on Water, Environment and Management Loughborough, WEDC Loughborough University of Technology

Jamal, K (1998) 'Water and Environmental Sanitation - Why Women?' in Pickford, J (ed) 24th WEDC Conference on Sanitation and Water for All Loughborough, WEDC Loughborough University Katko, T (1991) Paying for Water in Developing Countries Publications 74 Tampere, Tampere University of Technology, Finland 
Kayaga, S M (2002) 'The Influence of Customer Perceptions of Urban

Utility Water Services on Bill Payment Behaviour: Findings from Uganda' PhD Thesis, Loughborough University

Kervin, J B (1992) Methods for Business Research New York, HarperCollinsPublishers

Lasser, W M, Manolis, C, and Winsor, R D (2000) 'Service Quality Perspectives and Satisfaction in Private Banking' Journal of Services Marketing 14 (3) 244-271

Litwin, M S (1995) How to Measure Survey Reliability and Validity, The Survey Kit 7 London, Sage Publications

Mani, D, Onishi, T, and Kidokoro, T (1997) 'Estimating Willingness To Pay for WATSAN' in Pickford, J (ed) $23^{\text {rd }}$ WEDC Conference Proceedings on Water and Sanitation for All: Partnerships and Innovations Loughborough, WEDC, Loughborough University 
North, J H, and Griffin, C C (1993) 'Water Source as a Housing Characteristic: Hedonic Property Valuation and Willingness to Pay for Water' Water Resources Research, 29 (7) 1923-1929

Nunnally, J C (1978) Psychometric Theory $2^{\text {nd }}$ edition New York, MacGraw-Hill, Inc

Oliver, R L (1980) 'A Cognitive Model of the Antecedents and Consequences of Satisfaction Decisions' Journal of Marketing Research 17 (November 1980) 460-468

Oliver, R L (1999) ‘Whence Consumer Loyalty?’ Journal of Marketing 63 (Special Issue 1999) 33-44

Pedhazur, E J (1982) Multiple Regression in Behavioural Research:

Explanation and Prediction, $2^{\text {nd }}$ edition New York, Holt, Rinehart and Winston Inc 
Sansom, K, Coates, S, Njiru, C, and Franceys, R (2000) 'Strategic

Marketing to Improve Both Water Utility Finances and Services to

Poor Urban Water Consumers' Discussion Paper by Water

Engineering and Development Centre (WEDC) Loughborough

University

Sekeran, U (1992) Research Methods for Business: A Skill-Building

Approach. $2^{\text {nd }}$ edition New York, John Wiley and Sons Inc

Singh, B, Ramasubban, R, Bhatia, R, Briscoe, R, Griffin, C C and

Kim, C (1993) 'Rural Water Supply in Kerala, India: How to Emerge

From a Low-level Equilibrium Trap' Water Resources Research 29

(7) $1931-1942$

Slater, S F, and Narver, J C (1994) 'Does Competitive Environment

Moderate the Market Orientation-Performance Relationship?' Journal of Marketing 58 (January 1994) 46-55 
Taylor, S A, and Baker, T L (1994) 'An Assessment of the Relationship Between Service Quality and Customer Satisfaction in the Formation of Consumers' Purchase Intentions' Journal of Retailing 70 (2) $163-178$

Uganda, Statistics Department Ministry of Finance and Economic Planning (1994) The 1991 Population and Housing Census (National Summary) Entebbe, Author

Walker, J L (1995) 'Service Encounter Satisfaction: Conceptualised' Journal of Services Marketing 9 (1) 5-14

Water Utility Partnership (2000) Performance Indicators of Some African Utilities, Draft Edition Abidjan, Author

Whittington, D, Davis, J, and McClelland (1996) 'Implementing a Demand-driven Approach to Community Water Supply Planning: A Case Study of Lugazi, Uganda' Unpublished report to the World Bank 
Whittington, D, Okarafor, A, Okore, A, and McPhail, A, (1990)

'Strategy for Cost Recovery in the Rural Water Sector: A Case Study of Nsukka District, Anambra State, Nigeria' Water Resources Research, 26 (9) 1899-1913

World Bank, The (1993) 'The Demand for Water in Rural Areas:

Determinants and Policy Implications' The World Bank Research Observer 8 (1) 47-70 1993

World Health Organisation (WHO), and United Nations Children's Fund (UNICEF) (2000) Global Water Supply and Sanitation Assessment 2000 Report New York, Author

Zerah M (1997) 'Some Issues in Urban Water Management:

Household Response to Water Supply Unreliability in Delhi' Contributions CSH97/6 New Delhi, Centre De Sciences Humanes 


\section{Appendix 1: Psychometric Tests}

Owing to the fact that a new measurement instrument was used to collect data for this study, there was a need to perform psychometric analysis, in order to assess the reliability and validity of the questionnaire. Reliability of the two scales, Customer Satisfaction and Customer Loyalty was assessed using Cronbach's coefficient alpha (Coolican, 1994; Nunnally, 1978). The results showed alpha coefficients of 0.82 and 0.72 for Customer Satisfaction and Customer Loyalty respectively, higher than a coefficient of 0.7 , a minimum level recommended for preliminary research (Litwin, 1995; Nunnally, 1978).

Construct validity of the scales was established through exploratory factor analysis (Coolican, 1994). Using principal-components method, the scales were factor-analysed, and the resultant factor matrices subjected to orthogonal rotations in order to produce simpler interpretable structures (Nunnally, 1978). Customer Satisfaction was segregated into two sub-dimensions: one sub-dimension describing satisfaction toward 'software', and another one related satisfaction with 'hardware' quality attributes. Similarly, two factors were extracted from the construct of Customer Loyalty: items concerned 
with 'attitudinal loyalty', and 'action loyalty', respectively. 'Attitudinal loyalty' is the customer's expressions of affection and anticipated commitment to biased behavioural response in favour of the service firm; 'action loyalty' is what takes place when the customer converts the positive behavioural intentions into actions (Oliver, 1999). Both constructs had factor structures that conformed to the conceptual framework, hence providing evidence of construct validity.

\section{Appendix 2: Statistic Tests for Moderator Effects}

Prior to analysing moderator effects between two variables, there is need to demonstrate that there is a statistically significant relationship between the predictor variable and the criterion variable. Bivariate correlational analysis of Customer Satisfaction and Customer Loyalty produced a Pearson's correlation coefficient of $r=0.4, p<0.01$. A simple linear regression analysis shows that Customer Satisfaction explains about $15 \%$ of the variance in Customer Loyalty, with an Fstatistic of $71(p<0.001)$. These correlational analyses provide evidence of a statistically significant positive relationship between Customer Satisfaction and Customer Loyalty.

Moderator effects were tested using the moderated regression analysis framework advanced by Baron and Kenny (1986), and recommended 
by Taylor and Baker (1994); Caruana, Money and Berthon (2000); and Lasser, Manolis and Winsor (2000). Moderated regression analysis seeks to examine the change in R-square values that results during a hierarchical test of three regression equations involving the criterion variable, predictor variable, moderator variable, and the interaction term. The moderator hypothesis is supported if the interaction term is significant. Although there may be significant main effects of the predictor and moderator variable, these regression coefficients are not relevant in the examination of moderator effects (Baron and Kenny, 1986, p.1174).

In order to achieve clear interpretable and robust moderator terms in moderated regression analysis, the moderator variable should not be correlated with either the predictor variable or the criterion variable (Baron and Kenny, 1986). The results of non-parametric correlation analysis of the moderator variables with the predictor and criterion variables, respectively are displayed in Table II.

Insert Table II

The non-parametric correlations shown in Table II indicate that there are no significant relations between the hypothesized moderator variables and the criterion/predictor variables. Hence, moderated regression analysis may proceed without anticipating effects of multicollinearity. 
Moderated regression analysis was carried out in which Customer Loyalty and Customer Satisfaction were the criterion and predictor variables, respectively. Full regression models were created by combining the two study variables with dummy variables formed from categorical variables corresponding to each of the eight household characteristics. For each moderator variable, pairs of regression equations comprising of full and reduced models were created (Bohrnstedt and Knoke, 1982; Caruana, Money and Berthon, 2000; Dielman, 1991; Hardy, 1993; Pedhazur, 1982). Assuming a moderator variable with three categorical levels, a typical pair of equation is as follows:

Cust_Loy $=\mathrm{A}_{1}+\mathrm{b}_{1}($ Cust-Sat $)+\mathrm{b}_{2} \mathrm{H}_{1}+\mathrm{b}_{3} \mathrm{H}_{2}$ Reduced model

Cust_Loy $=\mathrm{A}_{2}+\mathrm{b}_{4}($ Cust-Sat $)+\mathrm{b}_{5} \mathrm{H}_{1}+\mathrm{b}_{6} \mathrm{H}_{2}+\mathrm{b}_{7} \mathrm{H}_{1} *($ Cust-Sat $)+\mathrm{b}_{8} \mathrm{H}_{2} *($ Cust-Sat $)$ Full model

In the equations shown above, Cust_Loy is Customer Loyalty; Cust_Sat is Customer Satisfaction; $\mathrm{H}_{1}$ and $\mathrm{H}_{2}$ are two of the categorical levels of the household characteristic; $b_{1}, b_{2}$, and $b_{3}$ are regression coefficients for the dummy terms in a reduced model; $b_{4}, b_{5}$, and $b_{6}$ are regression terms for the dummy variables in a full model; $b_{7}$ and $b_{8}$ are the interaction terms in the full model. The null hypothesis to be tested for each test variable is, "Regression coefficients for all the interactive terms in the full model are non-significant, i.e. $\mathrm{H}_{\mathrm{o}}: \mathrm{b}_{7}=$ 
$\mathrm{b}_{8}=0$ ". The alternative hypothesis is, "At least one of the regression coefficients for the interactive terms in the full model is non-zero, i.e. $\mathrm{H}_{\mathrm{a}}: \mathrm{b}_{7}=\mathrm{b}_{8} \neq 0 ”$

For each of the test moderator variables, hierarchical regression analysis was carried out for the pair of equations comprising the partial and full models. Subsequently, using analytical methods detailed in statistical books (e.g. Bohrnstedt and Knoke, 1982; Dielman, 1991; Hardy, 1993), partial F-statistics were computed, which results are displayed in Table III.

Insert Table III

Results displayed in Table III indicate that five of the eight test variables exert significant moderator effects $($ at $p<0.01)$ on the relationship between Customer Satisfaction and Customer Loyalty towards the water utility. Gender had the most significant interaction effect $(F=39.47, p<0.001)$, while "Use of alternative water", "Household size", and "Premise type" did not have significant effects at $\alpha=0.05$. However, it can be noted that the test variables "Household size" and "Premise type" exert interaction effects that are significant at $\alpha=0.05$. 
Table I: Socio-economic data of respondents

\begin{tabular}{|c|c|c|c|}
\hline \multirow{2}{*}{ Household Characteristics } & \multirow{2}{*}{$\begin{array}{l}\text { Valid Cases } \\
\text { (N) }\end{array}$} & \multicolumn{2}{|l|}{ Classification } \\
\hline & & Category & Frequency $(\%)$ \\
\hline Gender of household head & 523 & $\begin{array}{l}\text { Male } \\
\text { Female }\end{array}$ & $\begin{array}{l}61 \\
39\end{array}$ \\
\hline $\begin{array}{l}\text { Years of formal education } \\
\text { by household head }\end{array}$ & 508 & $\begin{array}{l}\text { Less than } 7 \text { years } \\
7-12 \text { years } \\
\text { Over } 12 \text { years }\end{array}$ & $\begin{array}{l}9 \\
21 \\
70\end{array}$ \\
\hline $\begin{array}{l}\text { Type of employment for } \\
\text { household head }\end{array}$ & 522 & $\begin{array}{l}\text { Govt employed } \\
\text { Self-employed } \\
\text { Others (housewife etc.) }\end{array}$ & $\begin{array}{l}46 \\
34 \\
20\end{array}$ \\
\hline Size of household & 522 & $\begin{array}{l}1-5 \text { people } \\
6-10 \text { people } \\
\text { Over } 10 \text { people }\end{array}$ & $\begin{array}{l}41 \\
44 \\
15\end{array}$ \\
\hline $\begin{array}{l}\text { Type of dwellings occupied } \\
\text { by household }\end{array}$ & 513 & $\begin{array}{l}\text { Shared buildings } \\
\text { Unshared buildings }\end{array}$ & $\begin{array}{l}51 \\
49\end{array}$ \\
\hline Type of tenure of dwellings & 520 & $\begin{array}{l}\text { Owned by Household } \\
\text { Institutional owned } \\
\text { Private, rented }\end{array}$ & $\begin{array}{c}70 \\
8 \\
22\end{array}$ \\
\hline $\begin{array}{l}\text { *Estimated household } \\
\text { income, per month }\end{array}$ & 414 & $\begin{array}{l}\text { Low, up to Ug. Shs. } 450,000 \\
\text { Middle, Ug.Shs. } 450,001-750,000 \\
\text { High, over Ug. Shs. } 750,000\end{array}$ & $\begin{array}{l}33 \\
40 \\
27\end{array}$ \\
\hline $\begin{array}{l}\text { Use of alternative sources of } \\
\text { water? }\end{array}$ & & $\begin{array}{l}\text { Yes } \\
\text { No }\end{array}$ & $\begin{array}{l}31 \\
69\end{array}$ \\
\hline
\end{tabular}

*1,500 Uganda Shillings (Ug. Shs.) was equivalent to 1 US Dollar at the time of the survey Source: Survey Data, 1999 
Table II: Non-parametric Correlations Between Hypothesized Moderator Variables (i.e. Household Characteristics) and the Predictor/Criterion Variables in the Moderated Regression Models

\begin{tabular}{|c|c|c|c|}
\hline \multirow{2}{*}{ Household Characteristics } & \multirow{2}{*}{$\begin{array}{l}\text { Measure of } \\
\text { Association } \\
\text { Used }\end{array}$} & \multicolumn{2}{|c|}{ Strength of Relationship } \\
\hline & & $\begin{array}{l}\text { Criterion Variable: } \\
\text { Customer Loyalty }\end{array}$ & $\begin{array}{l}\text { Predictor Variable: } \\
\text { Customer Satisfaction }\end{array}$ \\
\hline${ }^{\#}$ Gender & Eta & $0.044^{\mathrm{ns}}$ & $0.075^{\mathrm{ns}}$ \\
\hline $\begin{array}{l}{ }^{+} \text {Level of formal education by } \\
\text { household head }\end{array}$ & Gamma & $0.098^{\mathrm{ns}}$ & $0.069^{\mathrm{ns}}$ \\
\hline${ }^{+}$Size of household & Gamma & $0.042^{\mathrm{ns}}$ & $0.057^{\mathrm{ns}}$ \\
\hline $\begin{array}{l}{ }^{\#} \text { Type of occupation for } \mathrm{h} / \mathrm{h} \\
\text { head (formal or informal) }\end{array}$ & Eta & $0.004^{\mathrm{ns}}$ & $0.086^{\mathrm{ns}}$ \\
\hline $\begin{array}{l}\text { \#Premise type (shared or } \\
\text { unshared) }\end{array}$ & Eta & $0.057^{\mathrm{ns}}$ & $0.051^{\mathrm{ns}}$ \\
\hline $\begin{array}{l}{ }^{*} \text { Tenure type (family-owned } \\
\text { or not) }\end{array}$ & Eta & $0.003^{\mathrm{ns}}$ & $0.066^{\mathrm{ns}}$ \\
\hline${ }^{+}$Estimated household income & Gamma & $0.228^{\mathrm{ns}}$ & $0.081^{\mathrm{ns}}$ \\
\hline $\begin{array}{l}{ }^{\#} \text { Use of alternative water } \\
\text { source }\end{array}$ & Eta & $0.080^{\mathrm{ns}}$ & $0.045^{\mathrm{ns}}$ \\
\hline
\end{tabular}

ns : Correlations are not significant at $\alpha=0.05$.

+ 'Gamma' measure of association used for household characteristic measured on the ordinal scale

\# 'Eta' measure of association used for household characteristic measured on the nominal scale 
Table III: Summary of Analysis of Partial F-statistic for Determining the Level of Significance of the Interaction Effects of Household Variables on the Relationship between Customer Satisfaction and Customer Loyalty.

\begin{tabular}{l|c|c|c|c}
\hline \hline \multicolumn{1}{c|}{ Test variables } & $\begin{array}{c}\text { Valid number } \\
\text { of respondents } \\
\text { N (listwise) }\end{array}$ & $\begin{array}{c}\text { R-square for } \\
\text { full model }\end{array}$ & $\begin{array}{c}\text { R-square for } \\
\text { reduced model }\end{array}$ & $\begin{array}{c}\text { Partial F- } \\
\text { statistic }\end{array}$ \\
\hline Gender & 379 & 0.240 & 0.160 & $39.47^{* * *}$ \\
Education years & 381 & 0.216 & 0.164 & $8.25^{* * *}$ \\
Occupation (formal/informal) & 378 & 0.181 & 0.160 & $4.77^{* *}$ \\
Household size & 375 & 0.184 & 0.173 & $2.49^{\mathrm{ns}}$ \\
Premise type (shared/unshared) & 365 & 0.172 & 0.166 & $2.62^{\mathrm{ns}}$ \\
$\begin{array}{l}\text { Tenure type (family-owned or } \\
\text { not) }\end{array}$ & 373 & 0.185 & 0.164 & \\
Estimated household income & 348 & 0.182 & 0.157 & $5.23^{* *}$ \\
\hline \hline
\end{tabular}

ns - Not significant at $\mathrm{p}<0.05$

** $\quad$ Significant at $\mathrm{p}<0.01$

*** _ Significant at $\mathrm{p}<0.001$

Source: Survey Data, 1999 
Figure I: The conceptual framework for this research 


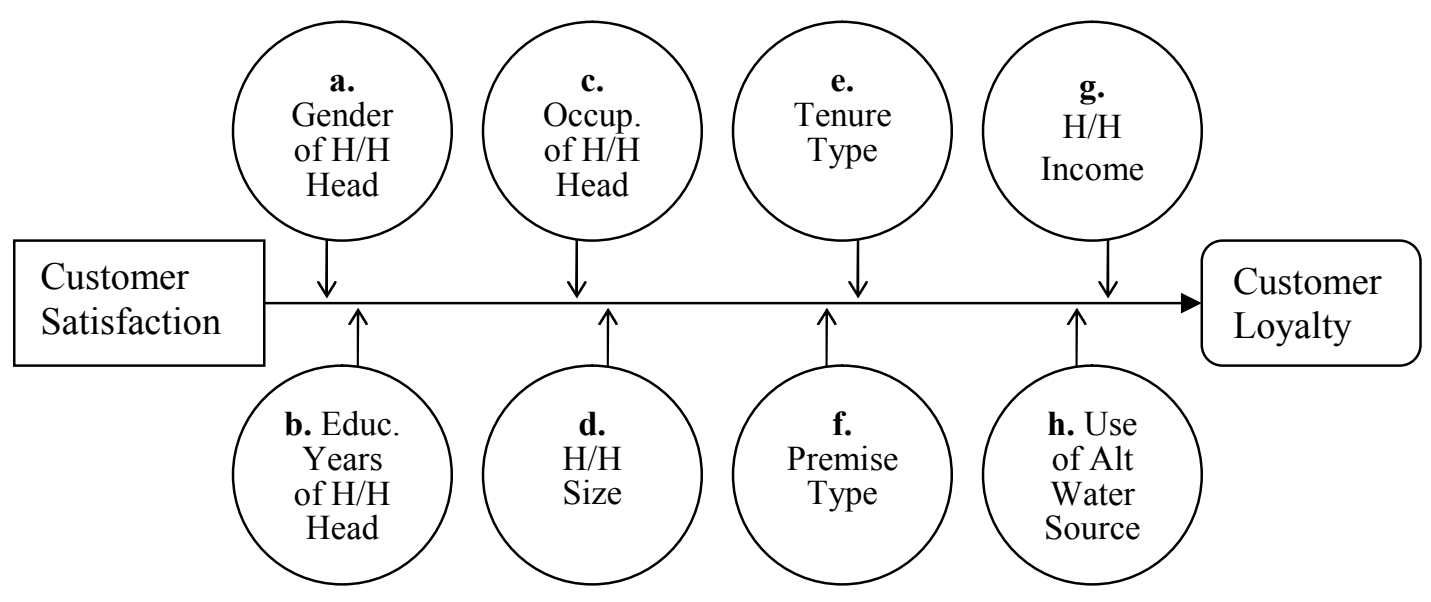

\section{LEGEND}

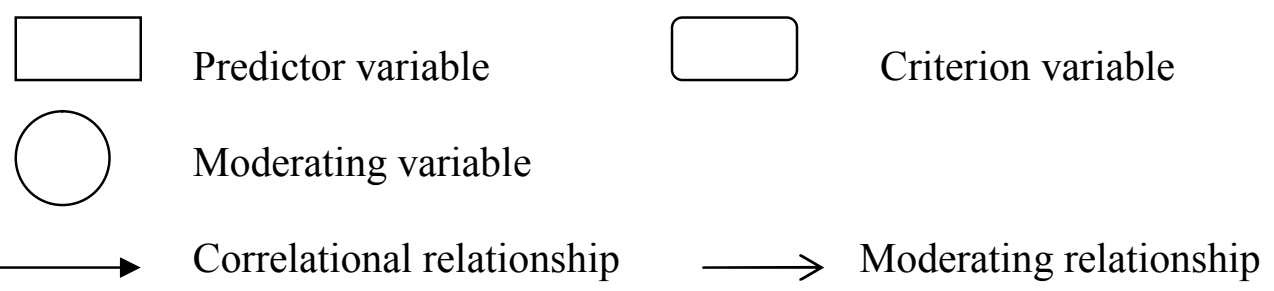

